\title{
$11 \beta$-Hydroxysteroid Dehydrogenase Type 1 Deficiency Prevents Memory Deficits with Aging by Switching from Glucocorticoid Receptor to Mineralocorticoid Receptor-Mediated Cognitive Control
}

\author{
Joyce L. W. Yau, ${ }^{1,2}$ June Noble, $^{2}$ and Jonathan R. Seckl ${ }^{1,2}$ \\ ${ }^{1}$ Centre for Cognitive Ageing and Cognitive Epidemiology, University of Edinburgh, and ${ }^{2}$ Endocrinology Unit, Centre for Cardiovascular Science, The \\ Queen's Medical Research Institute, Edinburgh EH16 4TJ, United Kingdom
}

Local brain amplification of glucocorticoids (GCs) by $11 \beta$-hydroxysteroid dehydrogenase type 1 (11 $\beta$-HSD1) plays a pivotal role in age-related memory deficits. $11 \beta$-HSD1 deficient mice are protected from spatial memory impairments with aging, but the underlying mechanisms are unknown. To determine which brain receptors [high-affinity mineralocorticoid receptors (MRs) or low-affinity glucocorticoid receptors (GRs)] are involved, spatial memory was measured in aged $11 \beta$-HSD1 ${ }^{-/-}$mice before and during intracerebroventricular infusion (10 d) of spironolactone (MR antagonist) or RU486 (GR antagonist). Aged C57BL/6J control mice showed impaired spatial memory in the Y-maze; this improved with GR blockade, while MR blockade had no effect. In contrast, aged $11 \beta$-HSD1 ${ }^{-1-}$ mice showed intact spatial memory that became impaired with MR blockade, but not GR blockade. Hippocampal MR and GR mRNA expression and plasma corticosterone levels were not significantly altered with spironolactone or RU486 in either genotype. These data support the notion that $11 \beta$-HSD1 deficiency in aging mice leads to lower intracellular GC concentrations in brain, particularly in the hippocampus, which activate predominantly MRs to enhance memory, while in aging C57BL/6J controls, the increased intracellular GCs saturate MRs and activate predominantly GRs, thus impairing memory, an effect reversed by GR blockade.

\section{Introduction}

Chronic glucocorticoid (GC) hypersecretion associates with agerelated cognitive decline in rodents and humans (Meaney et al., 1995; Yau et al., 1995; Lupien et al., 1998). 11 $\beta$-Hydroxysteroid dehydrogenase type 1 (11 $\beta$-HSD1) catalyzes intracellular regeneration of active GCs [corticosterone (CORT), cortisol] from inert 11-keto forms (11-dehydrocorticosterone, cortisone), thus locally amplifying GC action (Holmes and Seckl, 2006). The adult brain expresses $11 \beta$-HSD1 particularly in the hippocampus, a region important for memory and feedback regulation of the hypothalamic-pituitary-adrenal (HPA) axis (Jacobson and Sapolsky, 1991). Mice deficient in $11 \beta$-HSD1 throughout life are protected from hippocampus-dependent spatial learning and memory impairments associated with aging without reduction in the elevated circulating CORT levels seen with age (Yau et al.,

Received Nov. 24, 2010; revised Jan. 8, 2011; accepted Jan. 27, 2011.

This work was supported by a Medical Research Council (MRC) project grant (G0501596; J.L.W.Y., J.R.S.). J.L.W.Y. holds a Research Councils UK Academic Fellowship. J.L.W.Y. and J.R.S. are members of The University of Edinburgh Centre for Cognitive Ageing and Cognitive Epidemiology, part of the cross-council Lifelong Health and Wellbeing Initiative (G0700704/84698). Funding from the Biotechnology and Biological Sciences Research Council, Engineering and Physical Sciences Research Council, Economic and Social Research Council, and MRC is gratefully acknowledged. We thank Dr. Christopher Kenyon for his expert help with optimizing the method of tissue extraction of corticosterone in mouse brain samples.

Correspondence should be addressed to Dr. Joyce L. W. Yau, The Queen's Medical Research Institute, 47 Little France Crescent, Edinburgh EH16 4TJ, UK. E-mail: Joyce.Yau@ed.ac.uk.

DOI:10.1523/JNEUROSCI.6145-10.2011

Copyright $\odot 2011$ the authors $\quad 0270-6474 / 11 / 314188-06 \$ 15.00 / 0$
$2001,2007)$. The improved cognitive phenotype of aged $11 \beta$ HSD1 deficient mice likely occurs via lower intracellular CORT levels (Yau et al., 2001, 2007). However, GC-related mechanisms of cognitive effects down-stream of $11 \beta$-HSD1 are unclear, and the enzyme also catalyzes the conversion of 7-keto-cholesterol to $7 \beta$-hydroxycholesterol, which may be pertinent to cognition (Odermatt and Nashev, 2010).

GCs exert their effects on cognition via two subtypes of intracellular corticosteroid receptor: high-affinity mineralocorticoid receptors (MRs), which are almost saturated at basal levels of CORT, and lower-affinity glucocorticoid receptors (GRs), which become activated by high levels of CORT. The differential binding affinity of MR and GR allows the brain to cope with large fluctuations in circulating CORT levels and plausibly underlies the inverted U-shaped relationship between CORT levels and hippocampal electrophysiological and cognitive functions (Reul and de Kloet, 1985; Diamond et al., 1992), with lower CORT levels activating procognitive actions via MR, while chronically high "stress" levels of CORT saturate GR and impair performance in spatial memory tasks (Kim and Diamond, 2002; Avital et al., 2006). Moreover, MR is initially important for appraisal processes and choice of the appropriate behavioral response to deal with a challenge, while GR is important for storage of the experience in the memory to prepare for future challenges, behavioral adaptation, and recovery (de Kloet et al., 1999). While MRs and GRs assume opposite roles in regulating synaptic plasticity, particularly under stressful conditions in young animals 
A

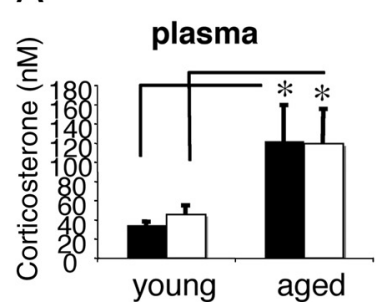

$\mathrm{B}$

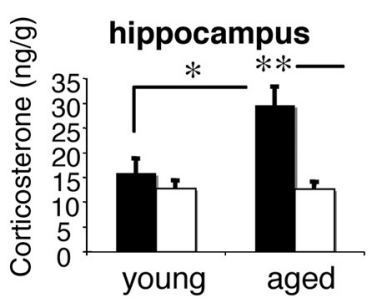

C

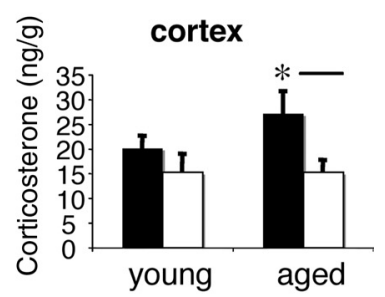

Figure 1. Corticosterone levels in plasma and brain of young (6-month-old) and aged (24-month-old) $11 \beta$-HSD1 ${ }^{-/-}$and C57BL/6J mice. $A$, Age increased plasma CORT levels in both $11 \beta$-HSD ${ }^{-1-}$ and C57BL/6J mice with no effect of genotype. $\boldsymbol{B}$, Age increased hippocampal CORT levels in C57BL/6J mice but not $11 \beta$-HSD1 ${ }^{-1-}$ mice. Hippocampal CORT levels were reduced in aged $11 \beta$-HSD1 ${ }^{-1-}$ mice. C, Age did not significantly increase cortex CORT levels, but $11 \beta$-HSD1 deficiency decreased cortex CORT levels in the aged mice. Filled bars, $\mathrm{C} 57 \mathrm{BL} / 6 \mathrm{~J}$ mice ( $n=6$ and 10 for young and aged, respectively); open bars, $11 \beta-\mathrm{HSD} 1^{-1-}$ mice ( $n=7$ and 9 for young and aged, respectively). All values are means \pm SEM. ${ }^{*} p<0.05 ;{ }^{* *} p<0.01$.

midline skin incision in the cranial region. A 30 gauge brain infusion cannula (Alzet) was implanted into the lateral ventricle [coordinates relative to bregma: anteroposterior $-1.2 \mathrm{~mm}$; lateral $+0.8 \mathrm{~mm}$ (midline); dorsoventral -2.5 $\mathrm{mm}$ from skull surface (Paxinos and Franklin, 2003)] and secured to the skull with cyanoacrylate. The cannula was connected by vinyl catheter tubing to the flow moderator of the Alzet osmotic mini-pumps (model 1002) filled with either the GR antagonist RU486 (mifepristone) $(100 \mathrm{ng} / \mathrm{h})$ or the MR antagonist spironolactone $(100 \mathrm{ng} / \mathrm{h})$ or vehicle $(30 \%$ propylene glycol in artificial CSF, $0.25 \mu \mathrm{l} / \mathrm{h}$ ) and implanted subcutaneously. Antagonist (Sigma) doses were according to published studies (van Haarst et al., 1996; Oitzl et al., 1998b; Yau et al., 1999).

In situ hybridization histochemistry. Brain sec-

(Avital et al., 2006), the correlation between high circulating CORT levels and impaired spatial memory in aged rats (Issa et al., 1990; Yau et al., 1995) implicates GR activation in age-related cognitive decline. However, neither receptor has been consistently associated directly with cognitive decline with aging, at either a genetic or a functional level (Lund et al., 2004; Kuningas et al., 2007; Soontornniyomkij et al., 2010).

Here, we explored the hypothesis that $11 \beta$-HSD 1 deficiency, by maintaining lower intracellular GC levels in aged $11 \beta$ HSD $1^{-/-}$mouse brain, minimizes occupancy of GR appreciably while optimally activating memory-supporting actions via MR, whereas in aged C57BL/6J controls, elevated GC levels acting via chronically increased GR activation underpin cognitive deficits.

\section{Materials and Methods}

Animals. Male mice homozygous for targeted disruption of the $11 \beta$ HSD1 gene (Kotelevtsev et al., 1997) and congenic on the C57BL/6J genetic background (Carter et al., 2009) and control C57BL/6J mice were bred and maintained within our biomedical research facility housed under standard conditions on a $12 \mathrm{~h}$ light/dark cycle (lights on at 07:00 A.M.), with food and water ad libitum until experimentation at either 6 months old (young) or 24 months old (aged). All procedures were performed in strict accordance with the U.K. Animals (Scientific Procedures) Act, 1986.

Spatial memory testing. Aged mice were tested in the Y-maze for hippocampal-dependent spatial recognition memory as described previously (Yau et al., 2007). In the training trial, each mouse was allowed to explore the maze for $5 \mathrm{~min}$ with one arm closed (novel arm) and returned to their home cage until the retrieval trial, during which they could explore freely all three arms of the maze for $2 \mathrm{~min}$. The time spent in the novel arm was calculated as a percentage of the total time in all three arms (Dellu et al., 1992; Conrad et al., 1999). A 1 min intertrial interval (ITI) was first used to confirm spontaneous novelty exploration and test vision. Mice were retested $4 \mathrm{~d}$ later with a $2 \mathrm{~h}$ ITI to measure baseline spatial memory performance. For each Y-maze test, the spatial cues around the maze were changed. MR or GR antagonist (or vehicle control) treatment was started 1 week after behavioral testing and all mice were retested in the Y-maze with a $2 \mathrm{~h}$ ITI during the 10th day of osmotic mini-pump infusion. Morning tail venesection blood samples were taken (8:30-9:30 A.M.) the day after the final Y-maze test for CORT measurements. Mice were culled by cervical dislocation the following morning, and brains were removed, snap frozen on soft dry ice, and stored at $-80^{\circ} \mathrm{C}$. Correct placement of cannula was confirmed histologically.

Surgery and drug treatment. Aged (24-month-old) mice (11 $\beta$ $\mathrm{HSD} 1^{-1-}$ and $\mathrm{C} 57 \mathrm{BL} / 6 \mathrm{~J}$ controls) were randomly assigned to intracerebroventricular GR antagonist, MR antagonist, or vehicle. Mice were anesthetized with halothane (3\% for induction, $1.5-2 \%$ for maintenance) and mounted in a stereotaxic apparatus (David Kopf Instruments). Buprenorphine $(0.05 \mathrm{mg} / \mathrm{kg})$ was given subcutaneously before a tions $(10 \mu \mathrm{m})$ at the levels of the anterior hippocampus and paraventricular nucleus were postfixed and hybridized with $\left[{ }^{35} \mathrm{~S}\right]$-UTP-labeled cRNA antisense probes transcribed in vitro from cDNA clones encoding rat MR and GR and quantified at the microscopic level as previously described (Yau et al., 1997).

Corticosterone assay. Plasma CORT levels were measured using an inhouse radioimmunoassay (RIA) (Al-Dujaili et al., 1981) modified for microtiter plate scintillation proximity assay (GE Healthcare). For brain CORT levels, steroids were extracted by solvolysis from the dissected tissues as described previously (Ebner et al., 2006) with modifications. Tissue homogenates in phosphate buffer were added slowly to $95 \%$ ethanol at $-30^{\circ} \mathrm{C}$ to avoid protein denaturation and steroid trapping. After incubation for $16 \mathrm{~h}$ at $-30^{\circ} \mathrm{C}$, extracts were centrifuged, dried, reconstituted in $40 \%$ methanol, and extracted using C18 Sep-Pak cartridges before RIA

Statistical analysis. Data are expressed as mean \pm SEM and were analyzed using either a one-way or two-way ANOVA followed by Scheffé $F$ tests post hoc as appropriate for individual between-group comparisons. The percentage time in the novel arm was compared with the other arms of the Y-maze by Student's paired $t$ test, as were before and after treatment times in the novel arm. Significance was set at $p<0.05$.

\section{Results}

Effect of aging and $11 \beta$-HSD1 deficiency on plasma and brain corticosterone levels

Basal plasma CORT levels increased with age in both $11 \beta$-HSD1 ${ }^{-/-}$ and C57BL/6J control mice $\left(F_{(1,28)}=6.3, p<0.05\right)$ (Fig. $\left.1 A\right)$, consistent with previous reports in rodents and humans (Issa et al., 1990; Yau et al., 1995; Lupien et al., 1998), but there was no effect of genotype. CORT concentrations in the hippocampus, which reflect free CORT from the periphery and intracellular CORT from $11 \beta$-HSD1 activity, increased with age in C57BL/6J mice $\left(F_{(1,28)}=5.7, p<\right.$ 0.005 ) but not in $11 \beta$-HSD $1^{-/-}$mice (Fig. $1 B$ ). Two-factor ANOVA revealed an effect of genotype $\left(F_{(1,28)}=12.2, p<0.01\right)$ and age $\times$ genotype interaction $\left(F_{(1,28)}=5.8, p<0.05\right)$. Aged $11 \beta$ HSD $1^{-1-}$ hippocampal CORT levels were significantly decreased (by $57 \%, p<0.01$ ) compared to aged controls. This reduction in hippocampal CORT was not evident in young $11 \beta$-HSD ${ }^{-/-}$mice (Fig. $1 B$ ). In the cortex, while $11 \beta$-HSD1 deficiency had no effect on CORT in young mice, levels in aged $11 \beta$-HSD ${ }^{-1-}$ mice were decreased by $44 \%\left(F_{(1,28)}=6.3, p<0.05\right)$ compared to aged controls (Fig. 1C).

\section{Spatial memory of aged $11 \beta-\mathrm{HSD} 1^{-/-}$and $\mathrm{C} 57 \mathrm{BL} / 6 \mathrm{~J}$ mice before treatment}

Baseline spatial memory performances of all aged (24-monthold) $\mathrm{C} 57 \mathrm{BL} / 6 \mathrm{~J}$ and $11 \beta$-HSD $1^{-/-}$mice were measured before randomization to treatment (vehicle, RU486, spironolac- 
A
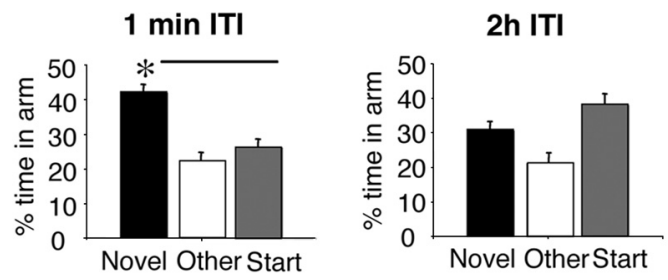

B

Aged C57BL/6J mice
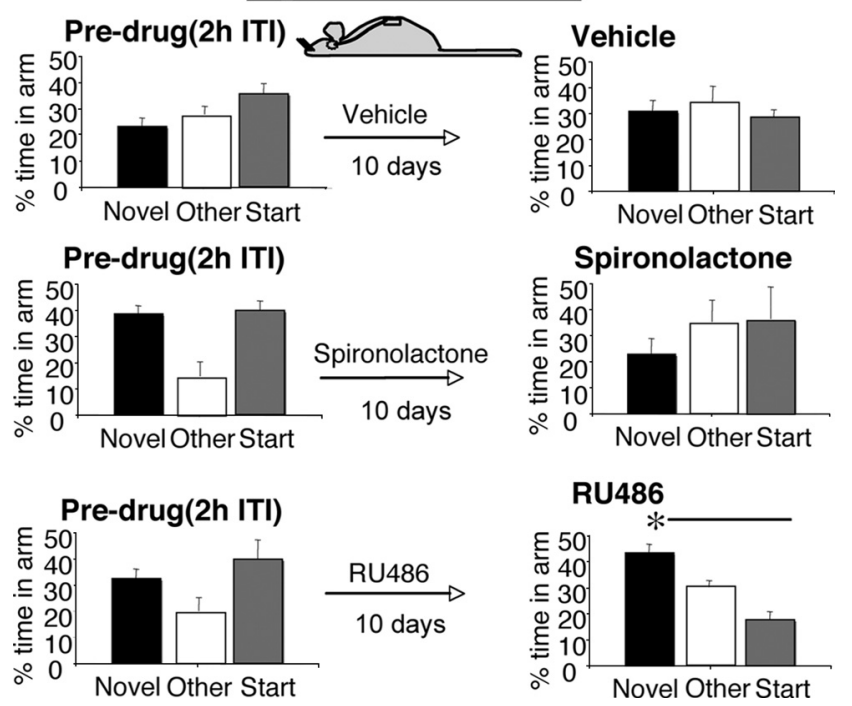

Figure 2. The impaired spatial memory of aged $(57 \mathrm{BL} / 6 \mathrm{~J}$ mice was reversed with central GR but not MR blockade. $\boldsymbol{A}$, Before antagonist treatment, aged $(57 \mathrm{BL} / 6 \mathrm{~J}$ mice ( $n=$ 19) spent more time in the novel arm of the Y-maze than other arms following a 1 min ITI, but with a $2 \mathrm{~h} \mathrm{ITI}$, they failed to distinguish the novel arm showing impaired spatial memory. $\boldsymbol{B}$, The impaired spatial memory of aged $(57 \mathrm{BL} / 6 \mathrm{~J}$ mice ( $n=7-8 /$ group) before the drug was reversed after $10 \mathrm{~d}$ intracerebroventricular RU486, with mice now spending more time in the novel arm than other arms. All values are means \pm SEM. ${ }^{*} p<0.05$.

tone). Both genotypes performed the immediate version (1 min ITI) of the Y-maze, showing similar neophilia, spending significantly more time in the novel arm than previously visited arms $(p<0.01)$ (Figs. $2 A, 3 A)$. However, aged C57BL/6J mice failed to recognize the novel arm following a $2 \mathrm{~h}$ ITI (Fig. $2 A$ ), while aged $11 \beta$-HSD $1^{-/-}$mice maintained spatial memory, spending significantly more time in the novel arm than previously visited arms $(p<0.001)$ (Fig. 3A) and than the novel arm in aged C57BL/6J controls $\left(F_{(1,44)}=14.3, p<\right.$ 0.001 ) (Fig. 2A).

Improved spatial memory in aged C57BL/6J mice following central GR blockade

The intracerebroventricular infusion of vehicle had no effect on the impaired spatial memory of aged C57BL/6J mice before the drug, showing the lack of any practice effect (novel arm before and after vehicle, paired $t$ test, $p=0.15$ ), and spironolactone did not affect the already impaired performance, although there was a trend for the mice to spend even less time in the novel arm than before the drug (paired $t$ test, $p=0.10$ ) (Fig. $2 B$ ). In contrast, RU486 improved spatial memory, with the mice spending significantly more time in the novel arm $(p<0.05)$ than in the previously visited arms and than in individual performances before RU486 ( $p<0.05)$ (Fig. $2 B)$.
A
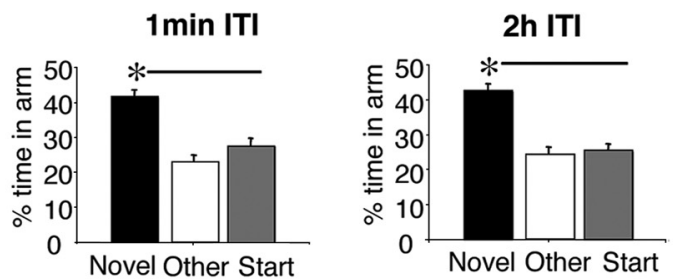

B

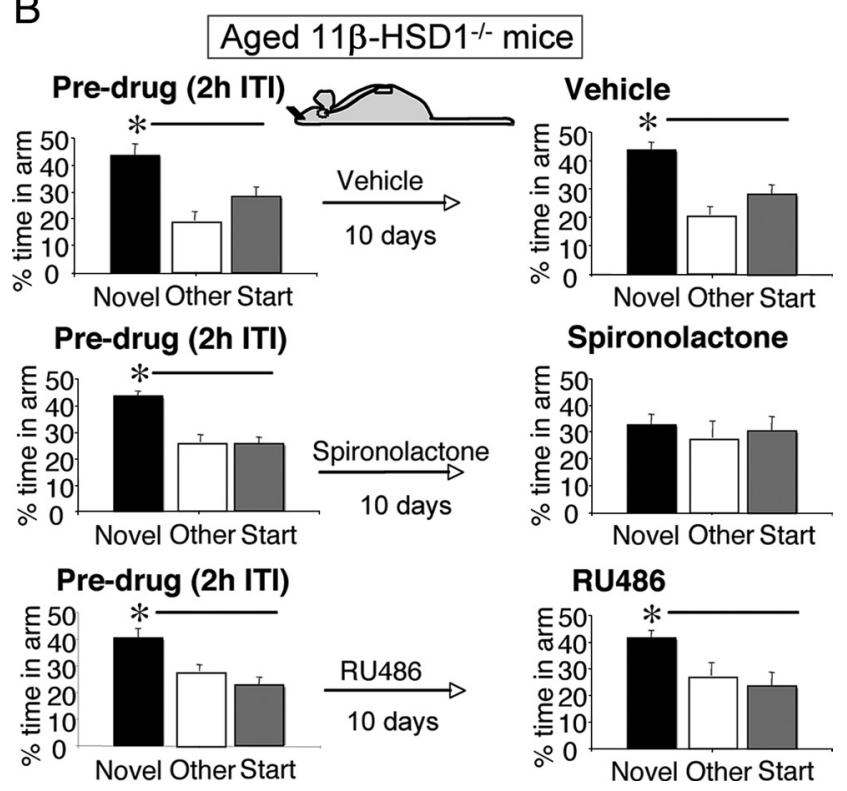

Figure 3. The intact spatial memory of aged $11 \beta-\mathrm{HSD} 1^{-/-}$mice became impaired with central MR but not GR blockade. $A$, Before antagonist treatment, aged $11 \beta$ HSD1 ${ }^{-1-}$ mice $(n=24)$ spent more time in the novel arm than other arms of Y-maze after both the $1 \mathrm{~min}$ and $2 \mathrm{~h} \mathrm{ITI}$, thus showing intact spatial memory. $\boldsymbol{B}$, This intact spatial memory of the aged $11 \beta$-HSD1 ${ }^{-1-}$ mice ( $n=7-8 /$ group) before the drug became impaired after $10 \mathrm{~d}$ intracerebroventricular spironolactone but not with vehicle or RU486. All values are means \pm SEM. ${ }^{*} p<0.05$.

Impaired spatial memory in aged $11 \beta-H S D 1^{-/-}$mice following central MR blockade

The maintained spatial memory of aged $11 \beta-\mathrm{HSD} 1^{-/-}$mice in the Y-maze ( $2 \mathrm{~h} \mathrm{ITI)} \mathrm{before} \mathrm{the} \mathrm{drug} \mathrm{was} \mathrm{not} \mathrm{altered} \mathrm{by} \mathrm{intrace-}$ rebroventricular infusion of vehicle (Fig. $3 B$ ). In contrast to aged C57BL/6J controls, RU486 had no impact on spatial memory in aged $11 \beta$-HSD $1^{-1-}$ mice with maintained recognition of the novel arm ( $p<0.05$ compared to other arms) (Fig. 3B). Spatial memory in aged $11 \beta$-HSD $1^{-/-}$mice was, however, impaired by intracerebroventricular spironolactone, with mice failing to recognize the novel arm and spending significantly less time there than before treatment $(p<0.05)$ (Fig. 3B).

Hippocampal corticosteroid receptor expression and plasma corticosterone levels

An alternative explanation for these findings is that $11 \beta$-HSD1 deficiency and/or receptor antagonist administration alters expression of GR and/or MR or plasma CORT levels. However, there was no significant effect of treatment (spironolactone or RU486) on MR or GR mRNA levels in any hippocampal subregion (Fig. $4 A, B$ ) or on GR mRNA in the paraventricular nucleus (PVN) of the hypothalamus (Fig. 4C). Basal plasma CORT levels in $\mathrm{C} 57 \mathrm{BL} / 6 \mathrm{~J}$ and $11 \beta$-HSD $1^{-/-}$mice, respectively, following spironolactone $(122 \pm 11 \mathrm{nM} ; 143 \pm 28 \mathrm{nM})$ or RU486 (116 $\pm 13 \mathrm{nM}$; $164 \pm 10 \mathrm{nM})$ treatments were not significantly different from vehicle controls ( $107 \pm 14 \mathrm{~nm} ; 143 \pm 21 \mathrm{~nm}$ ), although there was 

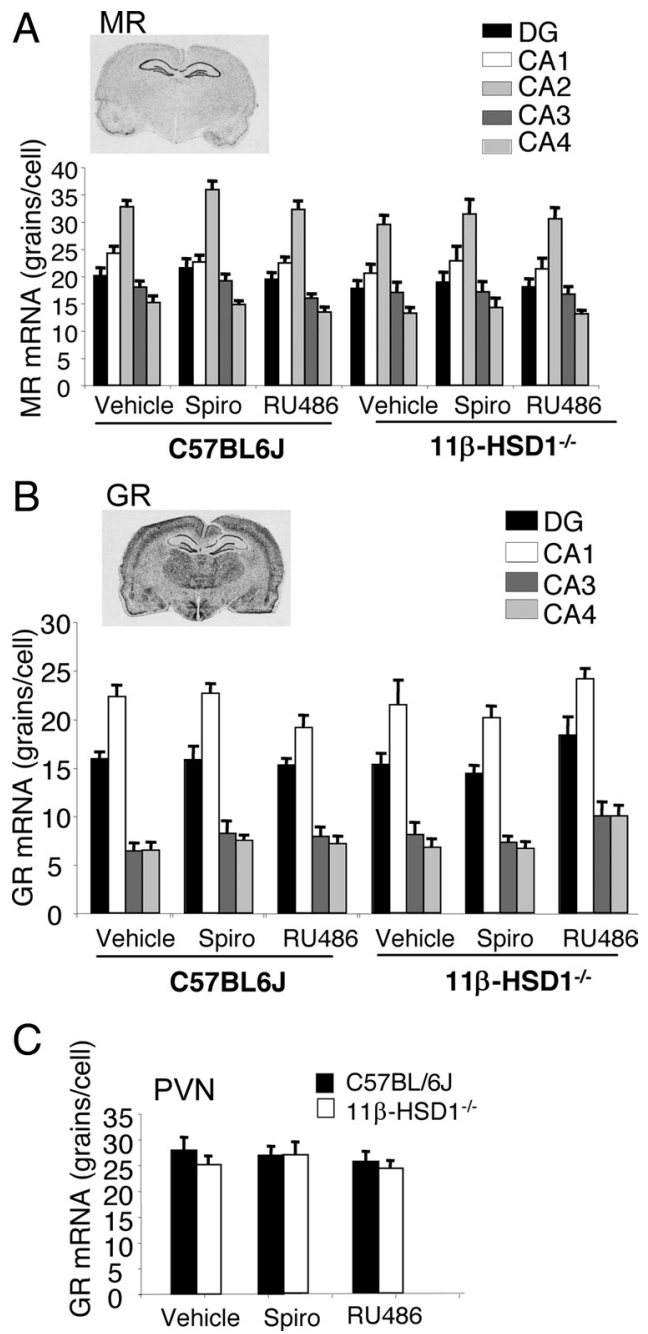

Figure 4. Brain MR and GR mRNA expression in aged $11 \beta-H S D 1^{-1-}$ and C57BL/6J mice following central MR and GR blockade. $\boldsymbol{A}-\boldsymbol{C}$, Expression of hippocampal MR $(\boldsymbol{A})$ and $\mathrm{GR}(\boldsymbol{B})$ and PVN GR (C) mRNA was unaffected by $11 \beta$-HSD1 deficiency and $10 \mathrm{~d}$ intracerebroventricular RU486 or spironolactone. All values are means \pm SEM.

an effect of genotype $\left(F_{(1,39)}=5.28, p<0.05\right)$, with significantly higher CORT levels in $11 \beta$-HSD $1^{-1-}$ mice treated with RU486.

\section{Discussion}

The present results show that spatial memory deficits in aged mice are ameliorated by central GR antagonism. In contrast, maintained spatial memory in aged $11 \beta$-HSD $1^{-1-}$ mice is reversed by central MR blockade. These data (1) suggest that (i) age-related memory deficits are associated with long-term brain GC excess acting via GR; (ii) such deficits are not due to irreversible molecular and structural changes in the aged brain, at least in mice; (iii) intracellular CORT levels appear crucial; and (iv) $11 \beta$ HSD1 deficiency, by keeping intracerebral CORT levels low with aging, allows spatial-memory-enhancing MR-mediated effects to predominate; and (2) afford clear evidence that GR and MR underpin distinct effects on cognition with aging.

The relationships between GCs, their receptors, and cognition are complex. In general, acute elevations of GCs tend to facilitate learning, notably in a fearful context, but impair retrieval (Roozendaal et al., 2006; Abrari et al., 2009) (Roozendaal, 2002). Chronic GC excess impairs hippocampal-dependent spatial/declarative memory formation (Lupien et al., 1997; Conrad, 2010).
Here, the cognition-enhancing effect of GR antagonism in aged C57BL/6J mice was marked. Indeed, chronic RU486 from middle age abolishes electrophysiological disturbances found in aged control mouse hippocampal slices (Talmi et al., 1996). However, chronic stress-induced morphological remodeling of prefrontal pyramidal neurons was not reversed with recovery from stress in aged rats (Bloss et al., 2010), suggesting that not all deleterious long-term effects of GCs are reversible in the aged animal. In contrast, in young rats, GR antagonism only modestly facilitates spatial learning in the "stressful" water maze when circulating CORT levels are elevated (Oitzl et al., 1998a,b), perhaps because young rats have lower CORT levels that barely occupy GR and/or have more robust cognition. The lack of effect of GR blockade on spatial memory in aged $11 \beta$-HSD $1^{-1-}$ mice suggests that their lower brain CORT levels were insufficient to substantially occupy GR (Ratka et al., 1989). In contrast, MR antagonism impaired spatial memory in aged $11 \beta$-HSD $1^{-1-}$ mice, consistent with the importance of MR occupancy in processing of hippocampusdependent memory (Oitzl and de Kloet, 1992; Conrad et al., 1997; Douma et al., 1998; Yau et al., 1999). Thus the balance of activated MR and GR, which are critical for neuronal excitability, stress responsiveness, and behavioral adaptation (De Kloet et al., 1998), appears shifted from predominantly GR effects in aged controls to predominantly MR actions in aged $11 \beta$-HSD $1^{--}$ mice. Many hippocampal GC-responsive genes are regulated either by MR or GR, with fewer genes responsive to both (Datson et al., 2001), supporting the notion that distinct pathways underpin the effects of the antagonists seen here.

$11 \beta$-HSD1 deficiency did not affect the expression of hippocampal MR and GR or PVN GR mRNAs in aged mice despite the decreased intracerebral CORT levels. This contrasts with increased GR mRNA in hippocampus and PVN of young $11 \beta$ HSD $1^{-1-}$ mice on the same strain background (Carter et al., 2009), which plausibly compensates for the lack of intracellular CORT regeneration by increasing cellular responsiveness. This mechanism appears lost in aged animals. The parallel rise in blood CORT levels in both genotypes with aging indicates that such implied reduced plasticity of GR, which occurs in normally aging rodents (Eldridge et al., 1989a,b), might contribute to the GC excess with aging. Moreover, in the aged mice of either genotype, continuous antagonism of brain MR or GR did not alter CORT levels. While acute blockade of brain MR increases basal circulating CORT levels in rats (Ratka et al., 1989; van Haarst et al., 1997), chronic blockade of brain MR had no effect on basal plasma CORT levels in young rats (Yau et al., 1999), as in our aged mice, suggesting that adaptations in the HPA axis have occurred. In contrast, acute blockade of brain GR has been shown to increase (van Haarst et al., 1997) or have no effect on (Ratka et al., 1989) plasma CORT levels, while chronic blockade of brain GR had no effect on basal morning plasma CORT levels (van Haarst et al., 1996), consistent with our present observation, but increased circadian peak levels of CORT (van Haarst et al., 1996). Although plasma CORT levels showed a trend to be higher in aged $11 \beta$-HSD $1^{-1-}$ mice than in aged C57BL/6J controls, this was only significant in the RU486-treated animals. However, the effects of intracerebroventricular RU486 in the aged $11 \beta$ $\mathrm{HSD}^{-/-}$mice were not a consequence of the higher plasma CORT per se, since spatial memory was unaffected compared to before treatment.

These findings suggest that decreasing GR activation/increasing MR activation, either by reducing brain GC levels with a selective $11 \beta$-HSD 1 inhibitor or by GR antagonism, may ameliorate memory impairments even in already aged individuals. The 
long-term use of GR antagonists in humans may be problematic, since chronic administration of RU486 (mifepristone) produces generalized GC resistance with high levels of cortisol in compensation (Bamberger and Chrousos, 1995). Perhaps intermittent therapy might exert net cognitive benefits. The use of selective $11 \beta$-HSD1 inhibitors to reduce the levels of GC in the aged brain, to reverse the balance of receptor activation from predominantly GR to predominantly MR, appears promising. Indeed, an $11 \beta$ HSD inhibitor improved aspects of cognitive function in elderly men and patients with type 2 diabetes without increasing HPA activity (Sandeep et al., 2004). Moreover, short-term treatment of already aged control mice with a CNS-active selective $11 \beta$ HSD1 inhibitor improves spatial memory over days (Sooy et al., 2010).

\section{References}

Abrari K, Rashidy-Pour A, Semnanian S, Fathollahi Y, Jadid M (2009) Posttraining administration of corticosterone enhances consolidation of contextual fear memory and hippocampal long-term potentiation in rats. Neurobiol Learn Mem 91:260-265.

Al-Dujaili EAS, Williams BC, Edwards CRW (1981) The development and application of a direct radioimmunoassay for corticosterone. Steroids $37: 157-176$

Avital A, Segal M, Richter-Levin G (2006) Contrasting roles of corticosteroid receptors in hippocampal plasticity. J Neurosci 26:9130-9134.

Bamberger CM, Chrousos GP (1995) The glucocorticoid receptor and RU 486 in man. Ann N Y Acad Sci 761:296-310.

Bloss EB, Janssen WG, McEwen BS, Morrison JH (2010) Interactive effects of stress and aging on structural plasticity in the prefrontal cortex. J Neurosci 30:6726-6731.

Carter RN, Paterson JM, Tworowska U, Stenvers DJ, Mullins JJ, Seckl JR, Holmes MC (2009) Hypothalamic-pituitary-adrenal axis abnormalities in response to deletion of 11beta-HSD1 is strain-dependent. J Neuroendocrinol 21:879-887.

Conrad CD (2010) A critical review of chronic stress effects on spatial learning and memory. Prog Neuropsychopharmacol Biol Psychiatry 34:742-755.

Conrad CD, Lupien SJ, Thanasoulis LC, McEwen BS (1997) The effects of type I and type II corticosteroid receptor agonists on exploratory behavior and spatial memory in the Y-maze. Brain Res 759:76-83.

Conrad CD, Lupien SJ, McEwen BS (1999) Support for a bimodal role for type II adrenal steroid receptors in spatial memory. Neurobiology Learn Mem 72:39-46.

Datson NA, van der Perk J, de Kloet ER, Vreugdenhil E (2001) Identification of corticosteroid-responsive genes in rat hippocampus using serial analysis of gene expression. Eur J Neurosci 14:675-689.

De Kloet ER, Vreugdenhil E, Oitzl MS, Joëls M (1998) Brain corticosteroid receptor balance in health and disease. Endocr Rev 19:269-301.

de Kloet ER, Oitzl MS, Joëls M (1999) Stress and cognition: are corticosteroids good or bad guys? Trends Neurosci 22:422-426.

Dellu F, Mayo W, Cherkaoui J, Le Moal M, Simon H (1992) A two-trial memory task with automated recording: study in young and aged rats. Brain Res 588:132-139.

Diamond DM, Bennett MC, Fleshner M, Rose GM (1992) Inverted-U relationship between the level of peripheral corticosterone and the magnitude of hippocampal primed burst potentiation. Hippocampus 2:421-430.

Douma BR, Korte SM, Buwalda B, la Fleur SE, Bohus B, Luiten PG (1998) Repeated blockade of mineralocorticoid receptors, but not of glucocorticoid receptors impairs food rewarded spatial learning. Psychoneuroendocrinology 23:33-44.

Ebner MJ, Corol DI, Havlíková H, Honour JW, Fry JP (2006) Identification of neuroactive steroids and their precursors and metabolites in adult male rat brain. Endocrinology 147:179-190.

Eldridge JC, Brodish A, Kute TE, Landfield PW (1989a) Apparent agerelated resistance of type II hippocampal corticosteroid receptors to down-regulation during chronic escape training. J Neurosci 9:3237-3242.

Eldridge JC, Fleenor DG, Kerr DS, Landfield PW (1989b) Impaired upregulation of type II corticosteroid receptors in hippocampus of aged rats. Brain Res 478:248-256.
Holmes MC, Seckl JR (2006) The role of 11beta-hydroxysteroid dehydrogenases in the brain. Mol Cell Endocrinol 248:9-14.

Issa AM, Rowe W, Gauthier S, Meaney MJ (1990) Hypothalamic-pituitaryadrenal activity in aged, cognitively impaired and cognitively unimpaired rats. J Neurosci 10:3247-3254.

Jacobson L, Sapolsky R (1991) The role of the hippocampus in feedback regulation of the hypothalamic-pituitary-adrenal axis. Endocr Rev 12:118-134.

Kim JJ, Diamond DM (2002) The stressed hippocampus, synaptic plasticity and lost memories. Nat Rev Neurosci 3:453-462.

Kotelevtsev Y, Holmes MC, Burchell A, Houston PM, Schmoll D, Jamieson P, Best R, Brown R, Edwards CRW, Seckl JR, Mullins JJ (1997) 11 $\beta$ hydroxysteroid dehydrogenase type 1 knockout mice show attenuated glucocorticoid-inducible responses and resist hyperglycemia on obesity or stress. Proc Natl Acad Sci U S A 94:14924-14929.

Kuningas M, de Rijk RH, Westendorp RG, Jolles J, Slagboom PE, van Heemst D (2007) Mental performance in old age dependent on cortisol and genetic variance in the mineralocorticoid and glucocorticoid receptors. Neuropsychopharmacology 32:1295-1301.

Lund PK, Hoyt EC, Bizon J, Smith DR, Haberman R, Helm K, Gallagher M (2004) Transcriptional mechanisms of hippocampal aging. Experimental gerontology 39:1613-1622.

Lupien SJ, Gaudreau S, Tchiteya BM, Maheu F, Sharma S, Nair NP, Hauger RL, McEwen BS, Meaney MJ (1997) Stress-induced declarative memory impairment healthy elderly subjects: relationship to cortisol reactivity. J Clin Endocrinol Metab 82:2070-2075.

Lupien SJ, de Leon M, de Santi S, Convit A, Tarshish C, Nair NPV, Thakur M, McEwen BS, Hauger RL, Meaney MJ (1998) Cortisol levels during human aging predict hippocampal atrophy and memory deficits. Nat Neurosci 1:69-73.

Meaney MJ, O'Donnell D, Rowe W, Tannenbaum B, Steverman A, Walker M, Nair NPV, Lupien S (1995) Individual differences in hypothalamicpituitary-adrenal activity in later life and hippocampal aging. Exp Gerontol 30:229-251.

Odermatt A, Nashev LG (2010) The glucocorticoid-activating enzyme 11beta-hydroxysteroid dehydrogenase type 1 has broad substrate specificity: physiological and toxicological considerations. J Steroid Biochem Mol Biol 119:1-13.

Oitzl MS, de Kloet ER (1992) Selective corticosteroid antagonists modulate specific aspects of spatial orientation learning. Behav Neurosci 106:62-71.

Oitzl MS, Fluttert M, de Kloet ER (1998a) Acute blockade of hippocampal glucocorticoid receptors facilitates spatial learning in rats. Brain Res 797:159-162

Oitzl MS, Fluttert M, Sutanto W, de Kloet ER (1998b) Continuous blockade of brain glucocorticoid receptors facilitates spatial learning and memory in rats. Eur J Neurosci 10:3759-3766.

Paxinos G, Franklin KBJ (2003) The mouse brain in stereotaxic coordinates, Ed 2. San Diego: Academic.

Ratka A, Sutanto W, Bloemers M, de Kloet ER (1989) On the role of brain mineralocorticoid (type I) and glucocorticoid (type II) receptors in neuroendocrine regulation. Neuroendocrinology 50:117-123.

Reul JMHM, de Kloet ER (1985) Two receptor systems for corticosterone in rat brain: microdissection and differential occupation. Endocrinology 117:2505-2511.

Roozendaal B (2002) Stress and memory: opposing effects of glucocorticoids on memory consolidation and memory retrieval. Neurobiol Learn Mem 78:578-595.

Roozendaal B, Okuda S, Van der Zee EA, McGaugh JL (2006) Glucocorticoid enhancement of memory requires arousal-induced noradrenergic activation in the basolateral amygdala. Proc Natl Acad Sci U S A 103:6741-6746

Sandeep TC, Yau JL, MacLullich AM, Noble J, Deary IJ, Walker BR, Seckl JR (2004) 11Beta-hydroxysteroid dehydrogenase inhibition improves cognitive function in healthy elderly men and type 2 diabetics. Proc Natl Acad Sci U S A 101:6734-6739.

Soontornniyomkij V, Risbrough VB, Young JW, Wallace CK, Soontornniyomkij B, Jeste DV, Achim CL (2010) Short-term recognition memory impairment is associated with decreased expression of FK506 binding protein 51 in the aged mouse brain. Age (Dordr) 32:309-322.

Sooy K, Webster SP, Noble J, Binnie M, Walker BR, Seckl JR, Yau JLW (2010) Partial deficiency or short-term inhibition of $11 \beta$-hydroxysteroid dehy- 
drogenase type 1 improves cognitive function in ageing mice. J Neurosci 30:13867-13872.

Talmi M, Carlier E, Bengelloun W, Soumireu-Mourat B (1996) Chronic RU486 treatment reduces age-related alterations of mouse hippocampal function. Neurobiol Aging 17:9-14.

van Haarst AD, Oitzl MS, Workel JO, de Kloet ER (1996) Chronic brain glucocorticoid receptor blockade enhances the rise in circadian and stress-induced pituitary-adrenal activity. Endocrinology 137:4935-4943.

van Haarst AD, Oitzl MS, de Kloet ER (1997) Facilitation of feedback inhibition through blockade of glucocorticoid receptors in the hippocampus. Neurochem Res 22:1323-1328.

Yau JL, Olsson T, Morris RG, Meaney MJ, Seckl JR (1995) Glucocorticoids, hippocampal corticosteroid receptor gene expression and antidepressant treatment: relationship with spatial learning in young and aged rats. Neuroscience 66:571-581.
Yau JL, Noble J, Seckl JR (1999) Continuous blockade of brain mineralocorticoid receptors impairs spatial learning in rats. Neurosci Lett 277:45-48.

Yau JL, Noble J, Kenyon CJ, Hibberd C, Kotelevtsev Y, Mullins JJ, Seckl JR (2001) Lack of tissue glucocorticoid reactivation in 11beta-hydroxysteroid dehydrogenase type 1 knockout mice ameliorates age-related learning impairments. Proc Natl Acad Sci U S A 98:4716-4721.

Yau JL, McNair KM, Noble J, Brownstein D, Hibberd C, Morton N, Mullins JJ, Morris RG, Cobb S, Seckl JR (2007) Enhanced hippocampal longterm potentiation and spatial learning in aged $11 \beta$-hydroxysteroid dehydrogenase type 1 knock-out mice. J Neurosci 27:10487-10496.

Yau J, Noble J, Seckl JR (1997) Site-specific regulation of corticosteroid and serotonin receptor subtype gene expression in the rat hippocampus following 3,4-methylenedioxymethamphetamine: role of corticosterone and serotonin. Neuroscience 78:111-121. 